\title{
Jasper Ridge Woody Plant Community Database
}

\author{
William K. Cornwell \& David Ackerly
}

\begin{abstract}
We sampled environmental variables and woody plant communities in $4420 x 20$-meter plots across the varied topography of a coastal California landscape. We characterized abundance of woody species in terms of cover, number of individuals, and diameter at breast height for large trees. We also measured 14 leaf, stem, and root traits for 54 woody plant species, including detailed intraspecific data for two traits with the goal of understanding the connection between traits and assembly processes in a variety of environmental conditions. Vegetation types in this dataset range from riparian forest to oak woodland to chaparral, with a dramatic gradient in the stature of the canopy. This report describes the available content in the Jasper Ridge Woody Plant Community Database (GIVD ID NA-US-003).
\end{abstract}

Keywords: California; chapparal; trait; woody plant.

GIVD Database ID: NA-US-003

\section{Jasper Ridge Woody Plant Community Database}

Scope: $4420 \times 20 \mathrm{~m}$ plots of the woody vegetation of coastal California. Vegetation types range from riparian forest to oak woodland to chaparral. Status: finished

Period: 2002-2002

Database manager(s): William K. Cornwell (wcornwell@gmail.com), David D. Ackerly (dackerly@berkely.edu)

Owner: Will Cornwell

Web address: http://www.phylodiversity.net/wcornwell/

Availability: free upon request

Online upload: no

Online search: no

Database format(s): text files

Export format(s): plain text file

Publication: Cornwell, W.K. and Ackerly D.D. 2009. Community assembly and shifts in the distribution of trait values across an environmental gradient in coastal California. Ecological Monographs 79: 109-126

Plot type(s): normal plots

Non-overlapping plots: 44

Total plot observations: 44

Plot-size range: $400-400 \mathrm{~m}^{2}$

Countries: US: $100.0 \%$

Forest: [NA] — Non-forest: [NA]

Guilds: only trees and shrubs: $100 \%$

Environmental data: altitude: 100\%; slope aspect: 100\%; slope inclination: 100\%; microrelief: 100\%; surface cover other than plants (open soil, litter, bare rock etc.): $100 \%$; other soil attributes: $100 \%$

Performance measure(s): cover: 100\%; number of individuals: 100\%; measurements like diameter or height of trees: $100 \%$

Geographic localisation: GPS coordinates (precision 25 m or less): $100 \%$

Sampling periods: [NA]

Information as of 2012-07-12; further details and future updates available from http://www.givd.info/ID/NA-US-003

William K. Cornwell* (wcornwell@gmail.com)

Systems Ecology, Vrije Universiteit, Amsterdam, NETHERLANDS

David D. Ackerly (dackerly@berkely.edu)

Department of Integrative Biology, University of California, 3060 Valley Life Sciences Building, Berkeley, UNITED STATES

*Corresponding author 